\title{
Class Participation And Writing Proficiencyofcommunication Skills Students: An Input To Total Quality Management PRACTICES IN AN OMANI CLASSROOM
}

\author{
Dr. Leovigildo Lito D. Mallillin, Dr. Amada G. Banaag, Dr. Rosalinda A. \\ Aguirre \\ Faculty of Foundation Studies-LecturerGulf College, Sultanate of
}

\begin{abstract}
Attendance and diligent participation in class are crucial to the success of a student specifically in a writing course. It is because writing requires practice through revising, tutoring, collaborating and brainstorming with the tutor and classmates. This paper sought to find the level of respondents' participation through attendance, the level of their writing skill, significant relationship between attendance and writing skill; and the predictive power and degree of influence of attendance on writing skills. It also encourages the application of total quality management in teaching academic courses such as in writing.
\end{abstract}

KEY WORDS Attendance, writing skills, class participation, total quality management

\section{INTRODUCTION}

Writing is one of the communication skills that is learned in schools as early as the pre elementary level. It is also considered to be the most complicated among the language skills because it involves tight rules as well as the knowledge of the other three communication skills such as listening, reading and speaking in order for one to write well. In the writing process also, specifically in the intermediate level, creative and critical thinking play a vital role for one to produce an acceptable output. As such, many learners dislike being given writing tasks and may not want to write at all if it is not to be marked.

The skill of writing as one of the four elements of communication skills has always been a part of any English language course for the reason that more and more people need to learn how to write in English for either academic or occupational purposes. It is however a difficult skill to master especially to foreign language learners. Mastering vocabularies and tenses are the main keys to get into good writing where students have to choose words and arrange them to form a sentence and eventually it develops to be a paragraph. Further, students also have to use compatible tense to express an event that happened at a certain time. These two must be mastered if students really want to succeed in academic and occupational writing, (Locke, 2014).

As a skill also, writing requires practice through revisions, tutoring and collaboration together with brainstorming ideas with others. These things cannot be done unless in the presence of other classmates thru class discussions which help in the improvement of a person's writing ability. As such, attendance and diligent participation are crucial to the success of a student specifically in writing.

(Ortega, 2010) emphasized that attendance to class is vital that students must attend their classes regularly and actively. Missing class should be rare occurrence otherwise it will interfere with learning and will have a negative effect in the students' performance and rating. Aside from this, there are also some benefits that learners can get when they attend class regularly. One benefit is that lectures supplement reading and writing assignments that gives students more ideas to deal with in all their courses. Another is that professors use questions or class discussions to enhance critical thinking skills of the students important in all areas of their program. If they attend class regularly also, it cuts the study time that they will spend later on. It is also during the regular class sessions that the important concepts are discussed and if this is missed by the students, there is a chance that misconceptions may arise. Lastly, is also during the regular class that teachers and students interact thereby clarifications of issues and confusing ideas are clarified or settled.

(Arulamplam,Naylor and Smith2007), found out that missing class has an adverse effect on performance but only for more able students. It was revealed that students tend to conform to their stereotype: morning classes have higher rates of absenteeism than the afternoon classes; with classes that start at 9 o'clock proving especially problematic. The results suggest that class attendance is a productive endeavor in such a way that it affects the performance of at least the able students negatively. This further asserts that there is no over provision of classes and that compulsory attendance is worthwhile.

Meanwhile, (Hoffman \&Lerche, 2016) in their investigation of data relating attendance and performance, their analysis showed that going to class has no significant impact on student performance in most 
specifications. Although the identification of causal effect may not be possible with the data at hand, the results suggest that that class attendance and studying on one's own may be substitutes.

Additionally, it is the responsibility of the tutor to provide opportunities for writing and encouragement for students who attempt to write. Another responsibility is to promote student success in writing by carefully monitoring their outputs to assess strength and weaknesses found and then teach them specific skills and strategies in response to student needs manifested in their work. Giving of careful feedback that will reinforce newly learned skills may also be given to avoid the initial problems seen to recur in the future. These responsibilities reveal that assessment and evaluation are integral to good writing instruction (Isaacson, 2016).

It is imperative then that students' writing need to be assessed and evaluated using tools that will objectively measure their skill. Their outputs may be evaluated on five product factors namely fluency, content, conventions, syntax and vocabulary. Writing samples also may be assessed across a variety of purposes for it reflects the writing performance of learners across different text structures and genres. Assessment is an essential component of effective instruction and according to Airasian (1996) in Isaacson (2016) there are three types of classroom assessment that can be applied to assess the writing skill of students. The first is called "sizing-up" assessments which are usually done on the first week of classes to provide the teacher with quick knowledge on the level where the students are to base their instruction. The second type is instructional assessments which are used for the daily tasks of planning instruction, giving feedback and monitoring student progress. The third type is the official assessments which are the periodic formal assessments to group, mark and report student achievement. Therefore, teachers use assessment for identifying strengths and weaknesses, planning instruction to fit diagnosed needs, evaluating instructional activities, giving feedbacks, monitoring performance and reporting progress. These are all done to ensure that there is quality in the outputs that the students will be handing over in the end of every term.

It is on this context that total quality management (TQM) finds it relevance in education. According to Mehrotra (2016) the concept of TQM is very much applicable in academics as many educators believe that the Deming's idea of TQM provides guiding principles for needed educational reform. The first of these principles is called the Synergistic Relationships which states that an organization must focus on its suppliers and customers and so teamwork and collaboration are essential. Therefore, the application of this concept is on the synergistic relationship between the suppliers and customers that when applied to a classroom scenario will produce better outputs or products from the collaborative efforts of teachers and learners.

The second principle is Continuous Improvement and Self Evaluation which is the total dedication to continuous improvement, personally and collectively. Within a Total Quality setting, administrators work collaboratively with customers: the teachers. In this modern world, it is the best interest of organizations to encourage everyone's potential by dedicating themselves to the continual improvement of their own abilities and of those people for whom they work and deal with. Total Quality in essence is a win-win approach which works to everybody's ultimate advantage and emphasizes self-evaluation. It also focuses on students' strengths, individual learning styles and multiple intelligences.

The third principle is a System of Ongoing Process which recognizes the organization as a system and the work done within is an ongoing process. The implication of this principle in education is that individual students and teachers are less to blame for failure in the system in which they work. Quality speaks to working on the system to identify and eliminate the flawed processes that cause the participants to fail. Since systems are of processes, the improvements made in the quality of those processes determine the quality of the product or output. The last principle is Leadership which is largely dependent on the top management level. The school teachers must establish the context in which students can best achieve their potential through the continuous improvement resulting from the collaborative efforts of both students and teachers.

It is in these contexts of student writing skills, assessment and total quality management that this study is pursued by the researchers.

\section{Statement of the Problem}

1. To determine the level of class participation in terms of student attendance.

2. To determine the level of writing skills in terms of

2.1 Focus

2.2 Development

2.3 Audience

2.4 Cohesion

2.5 Language and Style

2.6 Conventions

3. To determine if there is a significant relationship between class participation and the level of writing skills of the respondents.

4. To determine the predictive power and degree of influence of class participation on writing skills 


\section{HYPOTHESIS} respondents.

There is no significant relationship between class participation and the level of writing skills among the

\section{Research Design}

III. METHOD

The descriptive correlational is used in the study. Since this is a quantitative based. This is to measure the class participation and writing proficiency of the students in their communication skills subject. A correlation is simply defined as a relationship between two variables. The whole purpose of using correlations in research is to figure out which variables are connected. This basis of several statistical tests that result in a correlation coefficient, defined as a numerical representation of the strength and direction of a relationship (Kowalczyk, 2016).

\section{RESEARCH SUBJECTS}

The subjects of the study are the Omani students from the Faculty of Foundation Studies who are enrolled in the Semester 1, Communication Skills subject. Fifteen (15) students are utilized in the study that belongs to batch 251 in the academic year 2015-2016.

\section{SAMPLING TECHNIQUE}

This study employed purposive sampling which is also known as judgment, selective or subjective sampling) is a sampling technique in which researchers rely on their own judgment when choosing members of population to participate in the study.Purposive sampling is a non-probability sampling method and it occurs when "elements selected for the sample are chosen by the judgment of the researchers. Researchers often believe that they can obtain a representative sample by using a sound judgment, which will result in saving time and money (Saunders,Lewis, \&Thornhill,2012).

\section{Research Instrument}

1. Class Participation in terms of Student Attendance

\begin{tabular}{|c|c|c|}
\hline Scale & $\begin{array}{l}\text { Descriptive } \\
\text { Level }\end{array}$ & $\begin{array}{l}\text { Descriptive } \\
\text { Interpretation }\end{array}$ \\
\hline $29-35$ & Very high & The class participation in terms of students attendance is excellent \\
\hline $22-28$ & High & The class participation in terms of students attendance is very good \\
\hline $15-21$ & Moderate & The class participation in terms of students attendance is good \\
\hline $8-14$ & Low & The class participation in terms of students attendance is poor \\
\hline $0-7$ & Very low & The class participation in terms of students attendance is very poor \\
\hline
\end{tabular}

2. Level of writing proficiency

Scale: Writing Proficiency in terms of focus

\begin{tabular}{lll} 
Scale & $\begin{array}{l}\text { Descriptive } \\
\text { Level }\end{array}$ & \multicolumn{1}{c}{$\begin{array}{c}\text { Descriptive } \\
\text { Interpretation }\end{array}$} \\
$4.20-5.00$ & Very High & $\begin{array}{l}\text { The writing proficiency in terms of focus is excellent } \\
\text { The writing proficiency in terms of focus is very high }\end{array}$ \\
$3.40-4.19$ & High & The writing proficiency in terms of focus is good \\
$2.60-3.39$ & Moderate & The writing proficiency in terms of focus is poor \\
$1.80-2.59$ & Low & The writing proficiency in terms of focus is very poor \\
$1.00-1.79$ & Very Low & The
\end{tabular}

Scale: Writing Proficiency in terms of development

$\begin{array}{ll}\text { Scale } & \begin{array}{l}\text { Descriptive } \\ \text { Level }\end{array} \\ 4.20-5.00 & \text { Very high } \\ 3.40-4.19 & \text { High } \\ 2.60-3.39 & \text { Moderate } \\ 1.80-2.59 & \text { Low } \\ 1.00-1.79 & \text { Very low }\end{array}$

\section{Descriptive \\ Interpretation}

The writing proficiency in terms of development is excellent The writing proficiency in terms of development is very good The writing proficiency in terms of development is good The writing proficiency in terms of development is poor The writing proficiency in terms of development is very poor 
Scale: Writing Proficiency in terms of audience

$\begin{array}{ll}\text { Scale } & \begin{array}{l}\text { Descriptive } \\ \text { Level }\end{array} \\ 4.20-5.00 & \text { Very high } \\ 3.40-4.19 & \text { High } \\ 2.60-3.39 & \text { Moderate } \\ 1.80-2.59 & \text { Low } \\ 1.00-1.79 & \text { Very low }\end{array}$

\section{Descriptive \\ Interpretation}

The writing proficiency in terms of audience is excellent The writing proficiency in terms of audience is very good The writing proficiency in terms of audience is good The writing proficiency in terms of audience is poor The writing proficiency in terms of audience is very poor

Scale: Writing Proficiency in terms of cohesion

\begin{tabular}{lll} 
Scale & $\begin{array}{l}\text { Descriptive } \\
\text { Level }\end{array}$ & \multicolumn{1}{c}{$\begin{array}{c}\text { Descriptive } \\
\text { Interpretation }\end{array}$} \\
$4.20-5.00$ & Very high & $\begin{array}{l}\text { The writing proficiency in terms of cohesion is excellent } \\
\text { The writing proficiency in terms of cohesion is very good }\end{array}$ \\
$3.40-4.19$ & High & The writing proficiency in terms of cohesion is good \\
$2.60-3.39$ & Moderate & The writing proficiency in terms of cohesion is poor \\
$1.80-2.59$ & Low & The writing proficiency in terms of cohesion is very poor \\
$1.00-1.79$ & Very low & The
\end{tabular}

Scale: Writing Proficiency in terms of language and style

\begin{tabular}{lll} 
Scale & $\begin{array}{l}\text { Descriptive } \\
\text { Level }\end{array}$ & \multicolumn{1}{c}{$\begin{array}{c}\text { Descriptive } \\
\text { Interpretation }\end{array}$} \\
$4.20-5.00$ & Very high & $\begin{array}{l}\text { The writing proficiency in terms of language and style is excellent } \\
\text { The writing proficiency in terms of language and style is very good }\end{array}$ \\
$3.40-4.19$ & High & The writing proficiency in terms of language and style is good \\
$2.60-3.39$ & Moderate & The writing proficiency in terms of language and style is poor \\
$1.80-2.59$ & Low & The writing proficiency in terms of language and style is very poor \\
$1.00-1.79$ & Very low & The
\end{tabular}

Scale: Writing Proficiency in terms of conventions

\begin{tabular}{|c|c|c|}
\hline Scale & $\begin{array}{l}\text { Descriptive } \\
\text { Level }\end{array}$ & $\begin{array}{l}\text { Descriptive } \\
\text { Interpretation }\end{array}$ \\
\hline $4.20-5.00$ & Very high & The writing proficiency in terms of conventions is excellent \\
\hline 3.40 & High & The writing proficiency in terms of conventions is very good \\
\hline $2.60-3.39$ & Moderate & The writing proficiency in terms of conventions is good \\
\hline $1.80-2.59$ & Low & The writing proficiency in terms of conventions is poor \\
\hline $1.0-1.79$ & Very low & The writing proficiency in terms of conventions is very poor \\
\hline
\end{tabular}

Conceptual Framework

Independent Variable

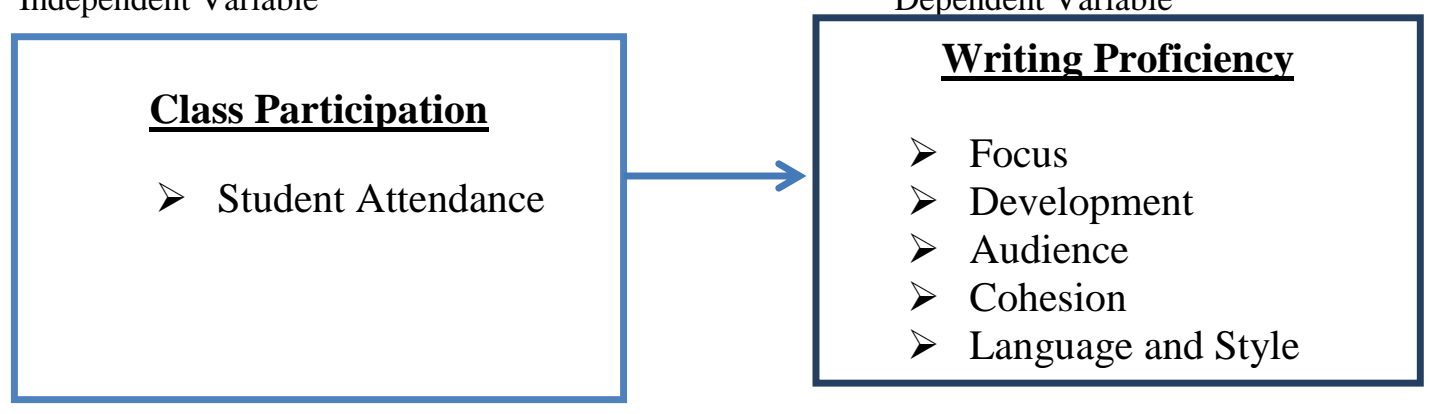

Figure 1.0

\section{DEFINITION OF TERMS}


The independent and dependent variables are operationally defined as used in the study.

1. Class participation refers to the number of times students attended his her classes for the whole semester in academic year 2015-2016.

2. Writing proficiency refers to the writing skills and proficiency in terms of focus, development, audience, cohesion, language and styles and convention among the students

\section{DELIMITATION AND LIMITATION OF THE STUDY}

The study is delimited to class participation or attendance during their communication skills subject where students are required to make essays. Their essays are evaluated based on the pre-defined criteria or standard rubrics in writing. This is delimited 15 students who enrolled in communication skills subject. Other batchers enrolled in communication skills are not included.

1. Class Participation

Results

Table 1.1. Level of Class Participation

\begin{tabular}{llll}
\hline Class Participation & SD & M & Description \\
\hline Student Attendance & 4.05 & 28.47 & High \\
\hline
\end{tabular}

The level of class participation in terms of attendance is high (mean $=28.27$ ) which means that class participation in terms of class attendance is very good.

\section{Writing Skills}

Table 1.2. Level of Writing Skills

\begin{tabular}{lccc}
\hline Writing Proficiency & $\boldsymbol{S D}$ & $\boldsymbol{M}$ & Description \\
\hline Focus & 0.47 & 2.7 & Moderate \\
Development & 0.27 & 2.6 & Moderate \\
Audience & 0.41 & 2.6 & Moderate \\
Cohesion & 0.41 & 2.5 & Low \\
Language and Style & 0.39 & 2.4 & Low \\
Convention & 0.39 & 2.3 & Low \\
Writing Skills & & & Low \\
\hline
\end{tabular}

1. The level of writing skills in terms of focus is moderate (mean=2.7) which means that writing proficiency in terms of focus is good.

2. The level of writing skills in terms of development is moderate (mean=2.6) which means that writing proficiency in terms of development is good.

3. The level of writing skills in terms of audience is moderate (mean=2.6) which means that writing proficiency in terms of audience is good.

4. The level of writing skills in terms of cohesion is low (mean=2.5) which means that writing proficiency in terms of cohesion is poor.

5. The level of writing skills in terms of language and style is low (mean=2.4) which means that writing proficiency in terms of language and style is poor.

6. The level of writing skills in terms of convention is low (mean=2.4 which means that writing proficiency in terms of convention is poor.

In order to interpret the strength of the relationship between class participation and writing proficiency, this research is guided by the following table of categorization:

\section{Computed $r$}

$$
+/-1.00
$$

Between $+/-0.75-+/-0.99$

Between $+/-0.51-+/-0.74$

\section{Descriptive Interpretation}

Perfect correlation

High correlation

Moderately high correlation 
Between $+/-0.31-+/-0.50$

Between +/- $0.01-+/-0.30$

0.0
Moderately low correlation

Low correlation

No correlation

\section{Correlation between Class Participation and Writing Participation}

Table 2. Correlation

\begin{tabular}{|c|c|c|c|}
\hline \multirow{2}{*}{ Writing Skills } & \multicolumn{3}{|c|}{ Student Attendance } \\
\hline & $r$-value & $p$-value & Interpretation \\
\hline Focus & -0.072 & 0.798 & Not significant \\
\hline Development & 0.256 & 0.357 & Not significant \\
\hline Audience & 0.067 & 0.812 & Not significant \\
\hline Cohesion & -0.044 & 0.877 & Not significant \\
\hline Language and Style & 0.207 & 0.458 & Not significant \\
\hline Convention & 0.144 & 0.608 & Not significant \\
\hline Writing Skills & 0.094 & 0.740 & Not significant \\
\hline
\end{tabular}

Strength of the correlation:

*. Correlation is significant at the 0.05 level (2-tailed).

1. Focus and class participation is moderately high correlated but not significant.

2. Development and class participation is low correlated but not significant.

3. Audience and class participation is moderately high correlated but not significant.

4. Cohesion and class participation is moderately low correlated but not significant.

5. Language and style and class participation is low correlated but not significant.

6. Convention and class participation is low correlated but not significant.

4. The predictive power and degree of influence of class participation on writing skills

Table 3: Predictive Power and Degree of Influence

\section{Writing Proficiency}

Independent Variables

\begin{tabular}{lcccc} 
& Coefficient & $\boldsymbol{p}$-value & Interpretation & $\begin{array}{c}\mathbf{R} \\
\text { Square }\end{array}$ \\
\hline Class Participation & 0.007 & 0.740 & Not significant & 0.009 \\
Constant & & & & \\
& 2.332 & 0.003 & \\
\hline
\end{tabular}

$W S=0.007 S A+2.332$

Degree of influence of Class Participation on Writing Proficiency is 9\%. 


\section{DISCUSSION}

This study revealed that the level of class participation shown by the subject yielded high or very good rating. This indicates that the class show big interest in coming to school and participate in class activities such as discussion with the teacher and their fellow students. It also shows that they are motivated to come and find enjoyment in the classroom. As pointed out in one literature attendance to class is vital that students must attend their classes regularly and actively.

As to the level of writing skills in terms of different elements, after careful analysis of data, it was found out that in terms of focus, development and audience, the students' outputs were rated good; as for cohesion, language and style and conventions- these were rated poor. The overall result for the level of writing skills is poor which does not quite reflect the effort in class attendance which was rated very good. Although literature says that attendance and diligent participation are crucial to the success of a student specifically in writing, the study at hand seems to negate the statement.

Further, as to the significant relationship between class participation and the level of writing skills of the respondents, the researchers found out that there is no significant relationship between the two variables. This result tends to affirm the finding of a study by Hoffman and Lerche that going to class has no significant impact on student performance. However, it negates the finding of another study conducted by Arumpalam et.al. that missing class has an adverse effect on performance.

Lastly, it was found out in this study that that the predictive power and degree of influence of class participation on writing skills is low and therefore supports results of other studies which state that class attendance has no great impact on performance.

\section{CONCLUSION}

1. The level of class participation among the respondents is very good.

2. The overall rating for the level of writing skills among the respondents is poor.

3. There is no significant relationship that exist between class participation and writing performance.

4. The predictive power and degree of influence of class participation on writing skills is low.

\section{RECOMMENDATION}

1. Sustain the interest of students in actively going to school and participating in class.

2. The writing tutors may find more ways to improve the writing skills of students.

3. The curriculum planners may incorporate the four principles of TQM in all courses especially in writing.

\section{REFERENCE}

[1] Arulampalam, W., Naylor, R. A., \& Smith, J. (2007). Am I missing something.The effects of absence from class on student performance.

[2] Devin Kowalczyk. (2016). Correlational Research Purpose and Examples. Retrieved from study.com/academy/lesson/correlational-research-definition-purpose-examples.html

[3] Hansen, B. D., \& Wills, H. P. (2014).The effects of goal setting, contingent reward, and instruction on writing skills.Journal of applied behavior analysis, 47(1), 171-175.

[4] Hoffmann, A. L., \&Lerche, K. (2016).Class attendance and university performance.cege Discussion papers, (286).

[5] Isaacson, S. (2016).Simple Ways to Assess the Writing Skills of Students with Learning Disabilities.www.readingrockets.org/article/simple-ways-assess-writing-skills-students-learning-dis

[6] Locke, W. (2014).Shifting academic careers: implications for enhancing professionalism in teaching and supporting learning.

[7] Mehrotra, D. (2006). Applying total quality management in academics.Six Sigma Magazine.

[8] Ortega, E. (2010). Cuntz-Pimsner.Retrieved from https://www. Math.edu./tomforde/attendingclass.

[9] Saunders, M., Lewis, P. \&Thornhill, A. (2012) "Research Methods for Business Students" $6{ }^{\text {th }}$ edition, Pearson Education Limited 